Chapman University

Chapman University Digital Commons

Pharmacy Faculty Articles and Research

School of Pharmacy

$10-27-2017$

\title{
Cyclic Peptide Conjugate of Curcumin and Doxorubicin as an Anticancer Agent
}

Shaban Darwish

Chapman University

Saghar Mozaffari

Chapman University

Keykavous Parang

Chapman University, parang@chapman.edu

Rakesh Tiwari

ChapmanUniversity, tiwari@chapman.edu

Follow this and additional works at: http://digitalcommons.chapman.edu/pharmacy_articles

Part of the Amino Acids, Peptides, and Proteins Commons, Cancer Biology Commons, Cell Biology Commons, Medicinal and Pharmaceutical Chemistry Commons, Other Pharmacy and Pharmaceutical Sciences Commons, and the Pharmaceutics and Drug Design Commons

\section{Recommended Citation}

Darwish S, Mozaffari S, Parang K, Tiwari R. Cyclic peptide conjugate of curcumin and doxorubicin as an anticancer agent. Tetrahedron Lett. 2017;58(49):4617-4622. doi: 10.1016/j.tetlet.2017.10.065

This Article is brought to you for free and open access by the School of Pharmacy at Chapman University Digital Commons. It has been accepted for inclusion in Pharmacy Faculty Articles and Research by an authorized administrator of Chapman University Digital Commons. For more information, 


\section{Cyclic Peptide Conjugate of Curcumin and Doxorubicin as an Anticancer Agent}

\section{Comments}

NOTICE: this is the author's version of a work that was accepted for publication in Tetrahedron Letters. Changes resulting from the publishing process, such as peer review, editing, corrections, structural formatting, and other quality control mechanisms may not be reflected in this document. Changes may have been made to this work since it was submitted for publication. A definitive version will subsequently be published in Tetrahedron Letters in 2017. DOI: 10.1016/j.tetlet.2017.10.065

The Creative Commons license below applies only to this version of the article.

\section{Creative Commons License}

\section{(c) 1 (1) 90}

This work is licensed under a Creative Commons Attribution-Noncommercial-No Derivative Works 4.0 License.

\section{Copyright}

Elsevier 


\section{Accepted Manuscript}

Cyclic peptide conjugate of curcumin and doxorubicin as an anticancer agent

Shaban Darwish, Saghar Mozaffari, Keykavous Parang, Rakesh Tiwari

PII:

S0040-4039(17)31369-2

DOI:

https://doi.org/10.1016/j.tetlet.2017.10.065

Reference:

TETL 49427

To appear in:

Tetrahedron Letters

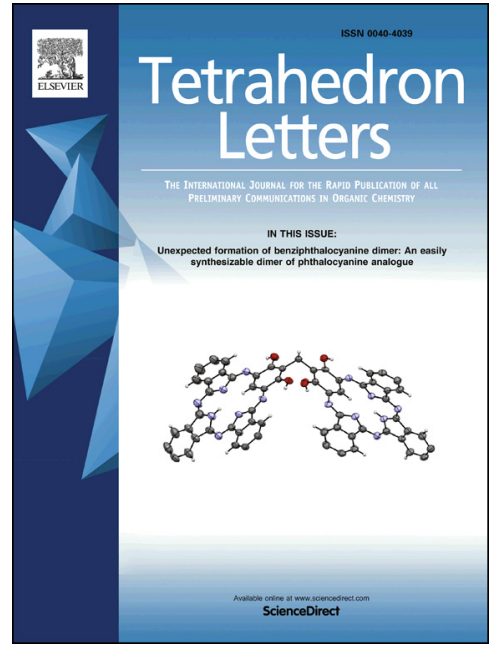

Received Date:

20 September 2017

Revised Date:

24 October 2017

Accepted Date:

26 October 2017

Please cite this article as: Darwish, S., Mozaffari, S., Parang, K., Tiwari, R., Cyclic peptide conjugate of curcumin and doxorubicin as an anticancer agent, Tetrahedron Letters (2017), doi: https://doi.org/10.1016/j.tetlet.2017.10.065

This is a PDF file of an unedited manuscript that has been accepted for publication. As a service to our customers we are providing this early version of the manuscript. The manuscript will undergo copyediting, typesetting, and review of the resulting proof before it is published in its final form. Please note that during the production process errors may be discovered which could affect the content, and all legal disclaimers that apply to the journal pertain. 


\section{Graphical Abstract}

To create your abstract, type over the instructions in the template box below.

Fonts or abstract dimensions should not be changed or altered.

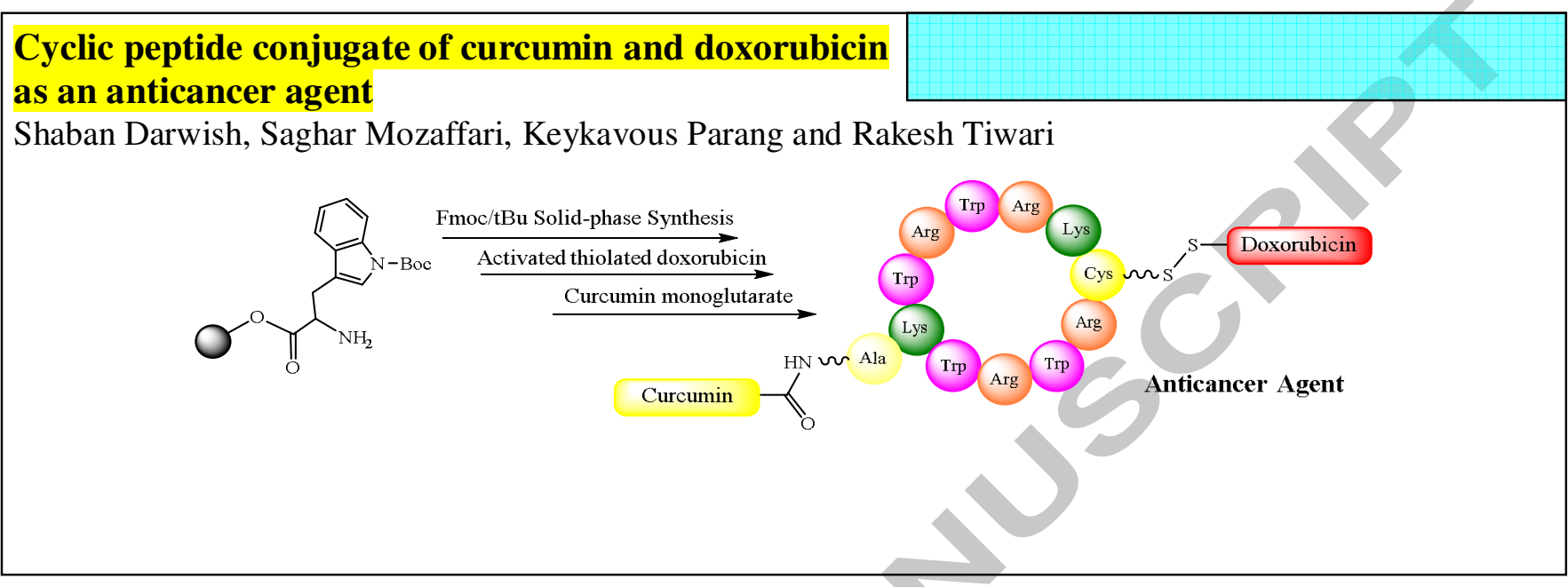




\title{
Cyclic peptide conjugate of curcumin and doxorubicin as an anticancer agent
}

\author{
Shaban Darwish ${ }^{\mathrm{a}, \mathrm{b}}$, Saghar Mozaffari ${ }^{\mathrm{a}}$, Keykavous Parang ${ }^{\mathrm{a}, *}$, and Rakesh Tiwari ${ }^{\mathrm{a}, *}$ \\ ${ }^{a}$ Center for Targeted Drug Delivery, Department of Biomedical and Pharmaceutical Sciences, Chapman University School of Pharmacy, Harry and Diane \\ Rinker Health Science Campus, Irvine, California 92618, United States. \\ ${ }^{b}$ Organometallic and Organometalloid Chemistry Department, National Research Centre, El Bohouth st., Dokki, Giza, Egypt
}

\section{ARTICLE INFO}

Article history:

Received

Received in revised form

Accepted

Available online

Keywords:

Antiproliferative activity

Combination therapy

Curcumin

Cyclic peptide

Doxorubicin

\section{ABSTRACT}

The hydrophobicity of curcumin creates hurdle towards its use in the anticancer therapy. Herein, we synthesized a curcumin-doxorubicin conjugated cyclic peptide scaffold to improve the solubility of curcumin and create a conjugate containing two anticancer agents. A solid-phase Fmoc/tBu solid phase methodology was used to synthesize a cell-penetrating nuclear targeting peptide with free thiol and amine groups, which was coupled with the activated doxorubicin (Dox) and curcumin, affording Dox-peptide-curcumin conjugate (DPCC) (10). The antiproliferative activity of the conjugate was evaluated in human leukemia carcinoma cell (CCRF-CEM), human ovarian carcinoma cell (SKOV-3), and normal kidney cell line (LLCPK). Cyclic peptide-doxorubicin conjugate (7) and DPCC (10) did not inhibit the proliferation of normal kidney LLCPK cells after $72 \mathrm{~h}$ incubation, but were cytotoxic in CCRF-CEM (73\% and $41 \%$, respectively) and SKOV-3 (55\% and 30\%, respectively) cells under similar conditions, suggesting selectivity of these compounds towards cancer cells while Dox was cytotoxic (60$79 \%$ ) in all three cell lines under similar conditions. 2009 Elsevier Ltd. All rights reserved.

\section{Introduction}

Cancer is a leading cause of death worldwide; nearly 1 in 6 deaths is reported due to cancer. ${ }^{1}$ There was 14.1 million new cancer cases and 8.2 million cancer deaths in 2012. This global burden is expected to increase to 21.7 million new cases and 13 million cancer deaths by $2030 .^{2}$ Thus, there is an urgent need to develop new drugs and/or use new strategies to combat cancer. Over the last decades, several chemical compounds either naturally or synthetically grabbed scientists' attentions for their anticancer activity; however, the situation is far from satisfactory, due to the toxicity related to nonspecific accumulation or their hydrophobicity, which are considered critical challenges for clinical applications. Therefore, developing a strategy to improve the physicochemical property of existing drugs will be required.

Curcumin (diferuloylmethane) is a hydrophobic polyphenol compound derived from Curcuma Longa (turmeric), has attracted attention as a promising natural product. ${ }^{3}$ An extensive research indicated that curcumin possesses several chemopreventive and pharmacological activities, ${ }^{4,5}$ including potent antioxidant ${ }^{6}$ and antitumor properties ${ }^{7}$ with extremely superior safety profiles. ${ }^{8-10}$ Its anticancer activities are mediated through the inhibition of NF-KB activity occurring through the down-regulation of IKK. ${ }^{11}$ Another study conducted by Gopinath et al. has provided evidence that curcumin decreases protein damage by quenching free radicals. ${ }^{12}$ Moreover, it can improve the cytotoxicity of some other anticancer molecules against different cancer cells. ${ }^{13}$ In spite of the promising biological effects of curcumin at the preclinical level, it fails clinically because of its poor bioavailability, ${ }^{14,15}$ rapid metabolism, and excretion. ${ }^{16,17}$ Thus, it will be beneficial to improve the physiochemical property of curcumin for the therapeutic applications.

Doxorubicin (Dox), which belongs to anthracycline antibiotic family, extracted from the bacteria Streptomyces pecetius, ${ }^{18}$ is one of the most vital antitumor compounds. Dox is highly effective in the treatment of various types of cancer including breast, acute lymphocytic leukemia, bladder, and prostate cancer. ${ }^{19-22}$ It has a unique mechanism of action through inhibition topoisomerase II, which interfere with DNA through insertion, inducing cancer cell apoptosis. ${ }^{23}$ Similar to curcumin, Dox has limited clinical use, due to its pharmacokinetic properties, such as short half-life and a high cumulative dose, leading to dose-independent side effects. ${ }^{24}$

Furthermore, the conventional single treatment can lead to the development of drug resistance over the course of therapy. ${ }^{25}$ Recently, combinational chemotherapy has emerged as one of the strategies that have gained attention to surmount the associated problems with the effectiveness of cancer treatment by reducing side effects and overcoming drug resistance, thereby achieving synergistic therapeutic efficacy. ${ }^{26,27}$ Additionally, the treatment success hinges on appropriate control over the timing, extent, and location of dosing. In this regard, drug delivery system techniques play an important role towards increasing the efficacy of the drug by delivering it to where it is needed, at the correct dose and extended release over a desired period. ${ }^{28-30}$

Our group has reported the use of the cyclic amphiphilic peptide as a drug delivery system. ${ }^{31-33}$ Moreover, the amphiphilic peptide was expected to increase the solubility of hydrophobic molecules such as curcumin. ${ }^{34}$ Dox is a hydrophilic anticancer 


\section{ACCEPTED MANUSCRIPT}

\section{Tetrahedron Letters}

agent. Cyclic $\left[\mathrm{W}(\mathrm{RW})_{4}\right]-$ Dox significantly inhibited the

carcinoma (MDA-MD-468) cells and showed 3.6-fold higher proliferation of human leukemia (CCRF-CEM) and breast

cellular uptake than Dox alone in SKOV-3 cells. ${ }^{33}$ We

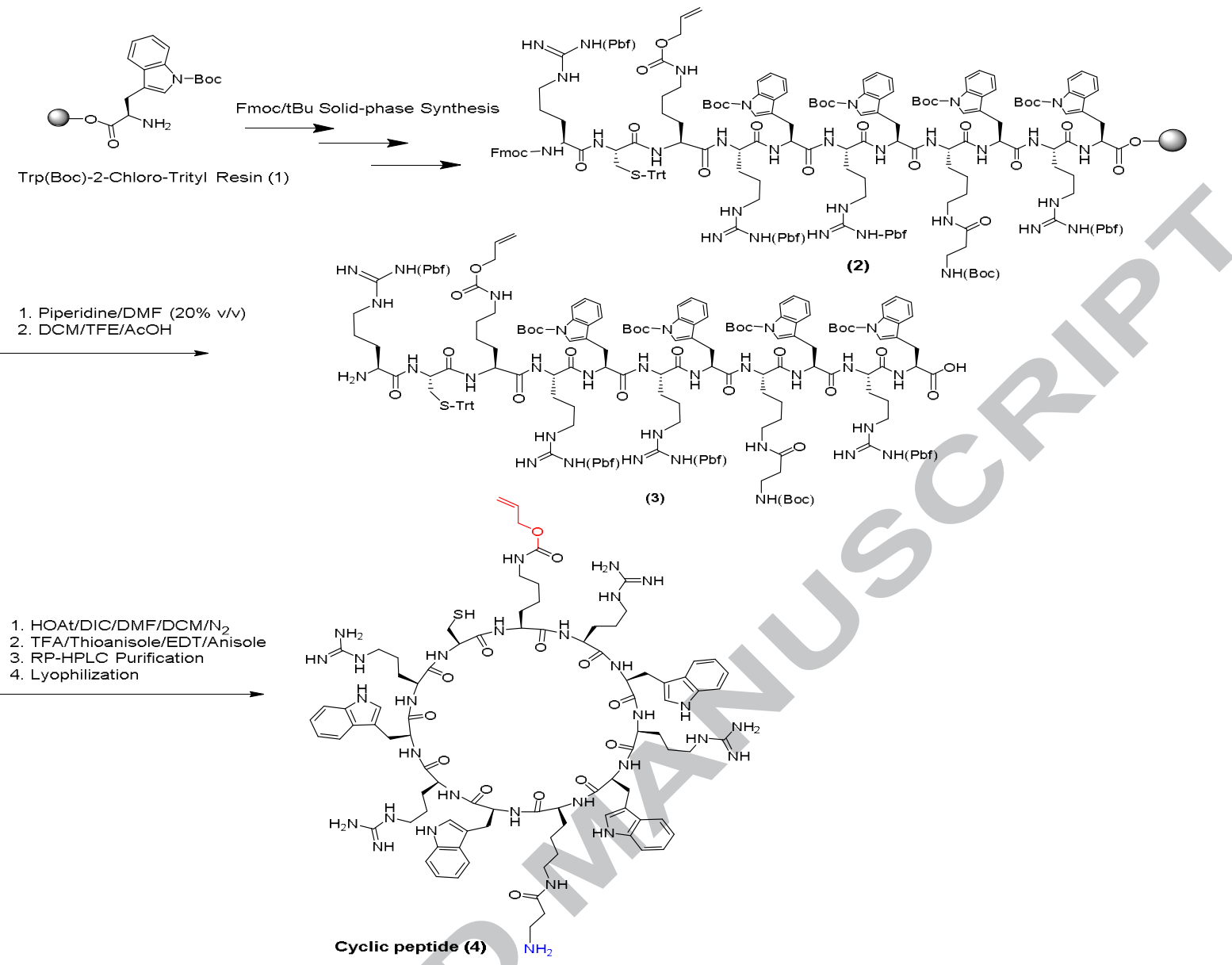

Scheme 1. Synthesis of cyclic amphiphilic peptide $\left[C(W R)_{4} K_{2}(\beta-A)\right](4)$.

hypothesized that physicochemical and/or biological properties of curcumin could be improved by using an amphiphilic cyclic peptide-Dox conjugate. Here we report the synthesis and evaluation of an anticancer agent using a cyclic amphipathic peptide.

\section{Results and discussion}

\subsection{Chemistry}

We have previously reported that cyclic peptides containing alternative tryptophan and arginine residues act as a molecular transporter. ${ }^{31,34}$ Here, a trifunctional cyclic peptide was prepared through conjugation of two anticancer drugs with a cellpenetrating cyclic peptide in multiple steps to improve the physicochemical properties and biological activities.

First, amphiphilic cyclic peptide $\left[\mathrm{C}(\mathrm{WR})_{4} \mathrm{~K}_{2}(\beta-\mathrm{A})\right]$ was synthesized using $\mathrm{Fmoc} / \mathrm{tBu}$ solid phase peptide chemistry. ${ }^{31}$ Fmoc and side chain-protected amino acids, mainly tryptophan, arginine, cysteine, lysine, and $\beta$-alanine were assembled on preloaded $\operatorname{Trp}(\mathrm{Boc})$-2-chlorotrityl resin (1) to generate side chain-protected linear peptide (2). Piperidine $(20 \% v / v)$ in DMF was used to remove Fmoc group at $N$-terminal, followed by the cleavage of the protected peptide from the resin with agitation in a mild acidic solution (dichloromethane (DCM), trifluoroethanol (TFE), and acetic acid) to generate the linear peptide with a free carboxylic group $(\mathbf{3}) .{ }^{35}$ Under diluted and anhydrous conditions, the linear protected peptide (3) was cyclized using coupling reagents, $N, N$ '-diisopropylcarbodiimide (DIC) and 1-hydroxyl-7azabenzotriazole (HOAt), followed by side chain deprotection generating the targeted amphiphilic cyclic peptide $\left[\mathrm{C}(\mathrm{WR})_{4} \mathrm{~K}_{2}(\beta-\right.$ A)] (4) (Scheme 1). The chemical structure of the conjugate confirmed by MALDI-TOF/TOF MS, showing the peak 1883 $\mathrm{Da}$, corresponding to $[\mathrm{M}+\mathrm{H}]^{+}$.

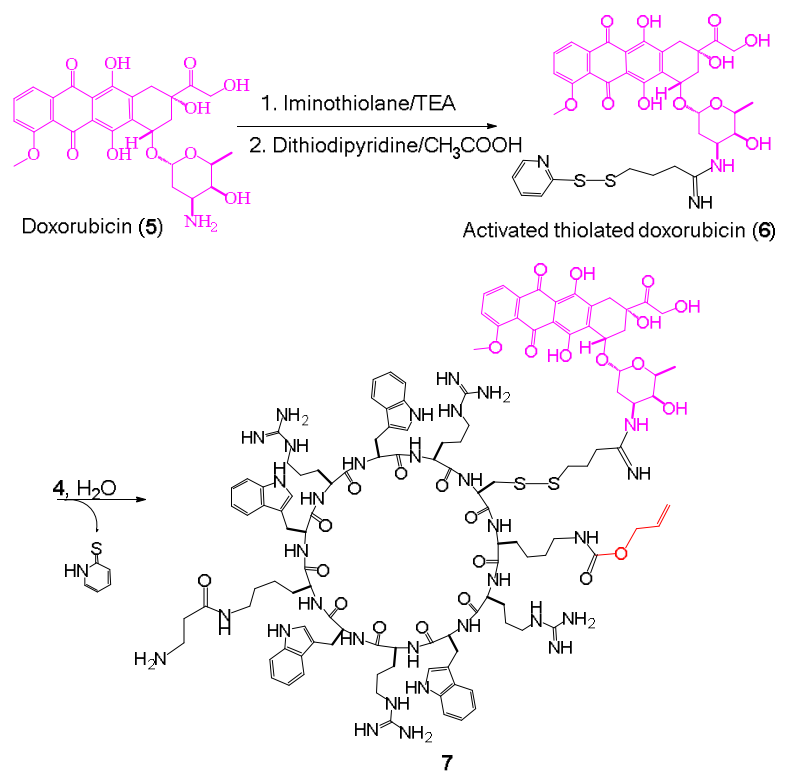


Scheme 2. Synthesis of Dox-SS-Pyridyl (6) and Dox-cyclic

Cyclic peptide $\left[\mathrm{C}(\mathrm{WR})_{4} \mathrm{~K}_{2}(\beta-\mathrm{A})\right]$ was used for conjugation with Dox through cysteine and using a disulfide bond. The disulfide linkage is relatively stable in extracellular compartments as compared to intracellular tumor fluid, where it gets hydrolyzed due to elevated glutathione (GSH) concentration. ${ }^{36-39}$ Therefore, Dox was modified with sulfhydryl group and activated using dithiodipyridine to generate Dox-SSPyridyl compound (6) (Scheme 2). The modified Dox (6) was conjugated with the thiol group on a cysteine residue of the cyclic peptide (4) under aqueous conditions affording Dox-SScyclic peptide (7) (Scheme 2). MALDI spectra showed a distinct peak at $2529 \mathrm{Da}$ corresponding to $[\mathrm{M}+4]^{+}$, in addition to two fragments one related to extrusion tetracyclic anthracycline aglycone at $2131 \mathrm{Da}$ and other for protonated cysteinyl peptide at $1887 \mathrm{Da}$, which may be due to specific fragmentation of disulfide bond under MALDI-MS. ${ }^{40}$

Curcumin (8) was modified with glutaric anhydride ${ }^{41}$ using a ring opening reaction of through a nucleophilic attack of one of the phenolic group under on anhydride carbonyl group under a basic condition, forming a stable ester linkage containing a free carboxylic group as shown in Scheme 3. The synthesis of monofunctional curcumin (9) permits the presence of one free phenolic group which is found important for the antioxidant activity of the molecule. The presence of glutarate chain decreases the steric hindrance for conjugation with the cyclic peptide- attached Dox (7).

Dox-peptide-curcumin conjugate (DPCC) $\mathbf{1 0}$ was synthesized by amide coupling reaction between the amine group of the doxorubicin-cyclic peptide (7) and the monocarboxylic acid group of curcumin compound (9) using phosphonium hexafluorophosphate (PyBOP) and 1-hydroxybenzotriazole derivatives $(\mathrm{HOBt})$ under basic medium at room temperature for three hours. ${ }^{42}$ The targeted compound was analyzed by MALDI, showing the peak at $2993 \mathrm{Da}$ corresponding to $[\mathrm{M}+4]^{+}$. In addition to two fragments 2597 and 2351 Da related to extrusion peptide conjugate (7).

tetracyclic anthracycline aglycone and protonated cysteinyl peptide as described above previously. (Scheme 3).

\subsection{The cytotoxicity assay of the synthetic compounds}

The cytotoxicity of all compounds was tested in two different cancer cell lines, human leukemia carcinoma cells (CCRF-CEM), human ovarian carcinoma cells (SKOV-3), in addition to normal kidney cell line (LLCPK), using MTS assay with concentration 5 $\mu \mathrm{M}$ and incubation time $24 \mathrm{~h}$ (Figure 1) and $72 \mathrm{~h}$ (Figure 2).

Curcumin did not inhibit the proliferation of CCRF-CEM cells as expected because of low solubility and precipitation in cell culture media. Cyclic peptide (4), Dox-attached cyclic peptide (7), and DPCC (10) showed less cytotoxicity than Dox after $24 \mathrm{~h}$ incubation. Dox-attached cyclic peptide (7) reduced the cell proliferation by $73 \%$ after $72 \mathrm{~h}$, but it was still less cytotoxic than Dox alone (79\%). The non-covalent physical mixture between Dox, the cyclic peptide, and curcumin reduced the cell proliferation by $78 \%$ and $84 \%$, slightly higher than that of Dox (77\% and $79 \%$ ) after incubation $24 \mathrm{~h}$ and $72 \mathrm{~h}$, respectively. Moreover, the physical mixture of Dox and the cyclic peptide exhibited slightly more inhibition when compared with Dox alone, showing $78 \%$ versus $77 \%$ after $24 \mathrm{~h}$, and $82 \%$ versus $79 \%$ after $72 \mathrm{~h}$ incubation.

In ovarian carcinoma cell line (SKOV-3), Dox-attached cyclic peptide (7) was found to be more cytotoxic as compared to compound DPCC (10) and reduced the cell proliferation by $55 \%$ versus $30 \%$, but still less active than Dox (62\%) after $72 \mathrm{~h}$ incubation. The physical mixing of Dox, $\left[\mathrm{C}(\mathrm{WR})_{4} \mathrm{~K}_{2}(\beta-\mathrm{A})\right]$, and curcumin reduced the cell proliferation by $34 \%$ and $80 \%$, a slightly higher than Dox (22\% and 62\%) after $24 \mathrm{~h}$ and $72 \mathrm{~h}$ incubation, respectively. Similarly, the physical mixture of Dox and the peptide showed slightly higher inhibition when compared with Dox (32\% versus 22\%) after $24 \mathrm{~h}$ incubation (Figures 1 and 2).

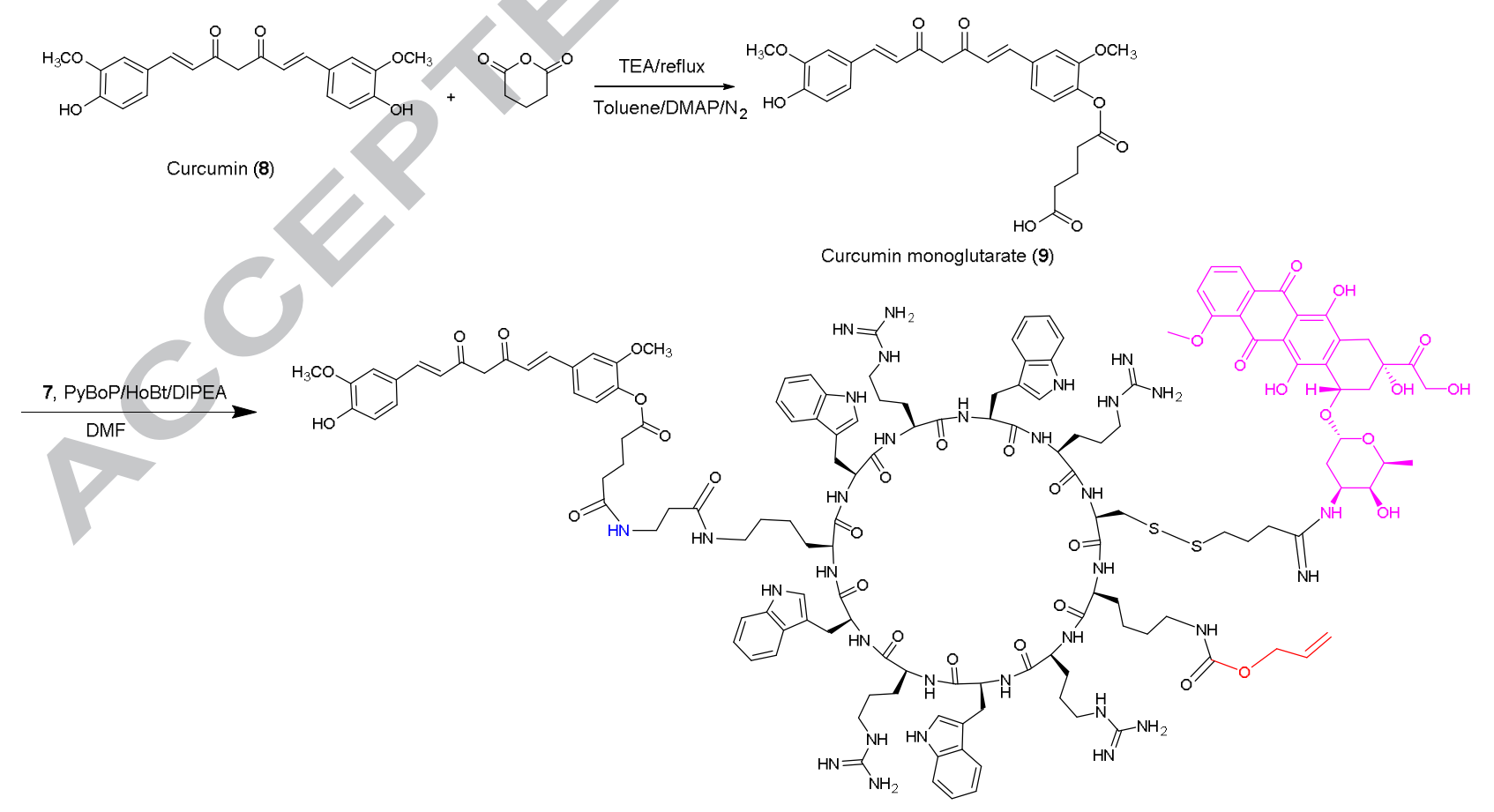

Curcumin-Cyclic Peptide-Doxorubicin (10)

Scheme 3. Synthesis of curcumin monoglutarate (9) and Dox-Cyclic Peptide-curcumin Conjugate (10). 
In normal kidney cell line, cyclic peptide (4) was not cytotoxic, but Dox-SS-cyclic peptide (7) and Dox-cyclic peptidecurcumin (10) exhibited less than $37 \%$ and $31 \%$ cytotoxicity, respectively, after $24 \mathrm{~h}$. On the other hand, the physical mixture of the cyclic peptide, curcumin, and Dox showed cytotoxicity (50\%) comparable to Dox $(50 \%)$ after $24 \mathrm{~h}$ incubation but was less toxic than Dox (55\% vs 60\%) after $72 \mathrm{~h}$ incubation. Regarding the physical mixture between the cyclic peptide and Dox, it showed slightly higher toxicity than Dox $(51 \%$ versus $50 \%$ ) after $24 \mathrm{~h}$ incubation but was slightly less toxic than Dox (58\% versus 60\%) after $72 \mathrm{~h}$ incubation (Figures 1 and 2).

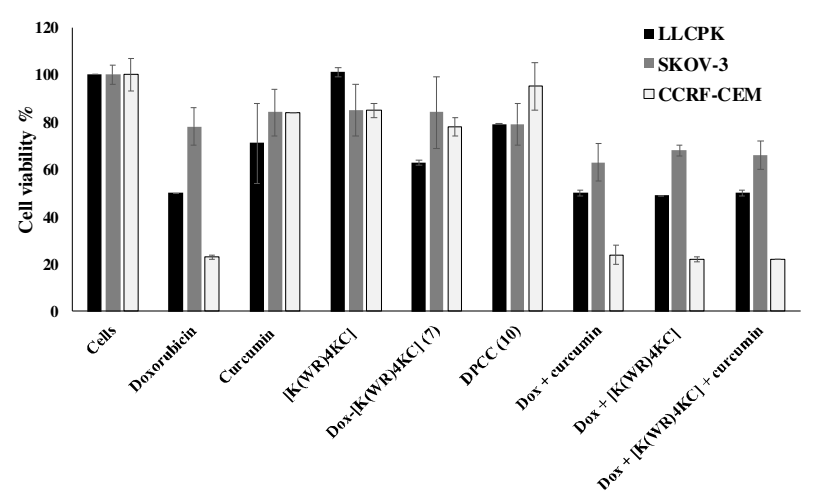

Figure 1. Comparison of cytotoxicity between Dox $(5 \mu \mathrm{M})$, curcumin (5 $\mu \mathrm{M})$, and cyclic peptide $(5 \mu \mathrm{M})$, Dox-SS-cyclic peptide $(5 \mu \mathrm{M})$, DPCC (5 $\mu \mathrm{M})$, and the corresponding physical mixture Dox $(5 \mu \mathrm{M})$, cyclic peptide ( 5 $\mu \mathrm{M})$, and curcumin $(5 \mu \mathrm{M})$ against human leukemia, ovarian carcinoma cells and normal kidney cell after $24 \mathrm{~h}$.

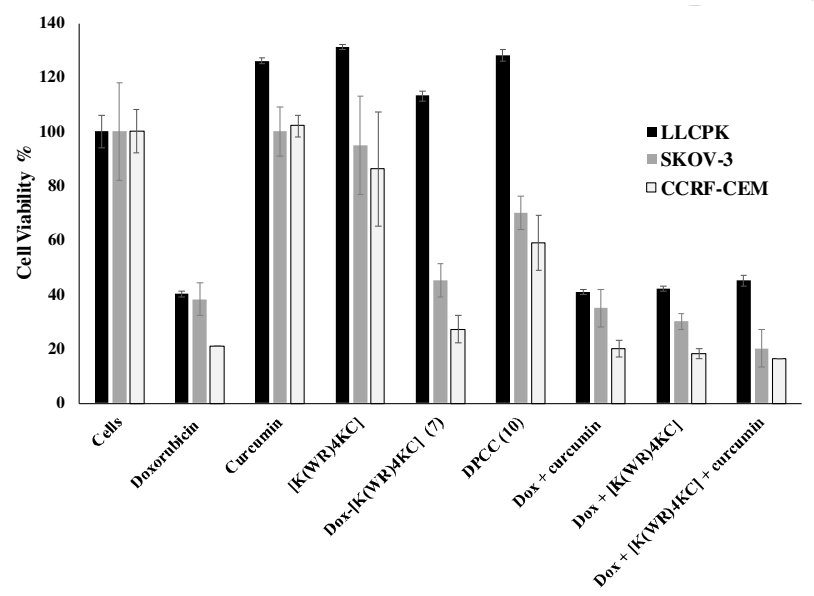

Figure 2. Comparison of cytotoxicity between Dox $(5 \mu \mathrm{M})$, curcumin $(5$ $\mu \mathrm{M})$, and cyclic peptide (5 $\mu \mathrm{M})$, Dox-SS-cyclic peptide $(5 \mu \mathrm{M})$, DPCC (5 $\mu \mathrm{M})$, and the corresponding physical mixture Dox $(5 \mu \mathrm{M})$, cyclic peptide ( 5 $\mu \mathrm{M})$, and curcumin $(5 \mu \mathrm{M})$ against human leukemia, ovarian carcinoma cells and normal kidney cell after $72 \mathrm{~h}$.

One of the major problems found with the anticancer agents is their cytotoxicity to both normal and cancer cells. As shown in Figure 2, Dox was cytotoxic (60-79\%) in all three cell lines after $72 \mathrm{~h}$ incubation. However, selective cytotoxicity was observed on leukemia and ovarian carcinoma cells by DPCC (10) and cyclic peptide-doxorubicin conjugate $\mathbf{7}$ in comparison to normal kidney cell lines after $72 \mathrm{~h}$ incubation. Compounds $\mathbf{7}$ and $\mathbf{1 0}$ did show any inhibition for the proliferation of normal kidney LLCPK cells after $72 \mathrm{~h}$ incubation. On the other hand, compounds 7 and
10 exhibited inhibition of proliferation of CCRF-CEM (73\% and $41 \%$, respectively) and SKOV-3 (55\% and 30\%, respectively) cells under similar conditions, suggesting selectivity of these compounds towards cancer cells. The data demonstrate selective cytotoxic effect by DPCC (10) and cyclic peptide-Dox conjugate 7 in cancer cells.

\section{Conclusions}

A synthetic methodology was developed for the synthesis of a conjugate containing an amphipathic cyclic peptide, Dox, and curcumin. The cyclic amphiphilic peptide containing lysine and cysteine residues was synthesized using Fmoc/tBu solid phase methodology. Both curcumin and Dox were modified by the reaction of glutaric anhydride and 2-iminothiolane, respectively. Dox-cyclic peptide (7) was reacted with curcumin monoglutarate to Dox-cyclic peptide-curcumin, which was characterized by MALDI-TOF. The purity of the compounds was confirmed by analytical HPLC. The antiproliferative assay of the synthesized compounds showed that Dox-cyclic peptide conjugate exhibited a significantly higher cytotoxicity than the corresponding DPCC (10) but still less than Dox in human leukemia and human ovarian carcinoma cells. The physical mixture of Dox, $\left[\mathrm{C}(\mathrm{WR})_{4} \mathrm{~K}_{2}(\beta-\mathrm{A})\right]$ and curcumin showed a considerable activity higher than Dox after $24 \mathrm{~h}$ and $72 \mathrm{~h}$ incubation. Overall, DPCC (10) and compound (7) were found to be more selective towards cancer cells vs normal cells used after $72 \mathrm{~h}$ incubation.

\section{Acknowledgments}

The authors greatly acknowledge financial support for this research from Chapman University School of Pharmacy and Egyptian Cultural Affairs and Mission Sector, Egypt.

\section{Supplementary Material}

The experimental details, HPLC, NMR, and Mass spectra of synthesized compound can be found in the supplementary file.

\section{References}

1. https://www.cancer.org/research/cancer-facts-statistics/global.html

2. Ferlay J, Soerjomataram I, Ervik M, et al. GLOBOCAN 2012 v1.0, Cancer Incidence and Mortality Worldwide: IARC CancerBase No. 11 [Internet]. Lyon, France: International Agency for Research on Cancer; 2013. Available from: http://globocan.iarc.fr, accessed on day/month/year.

3. Foozie S,Maedeh M,Ghasem D, Ali A. Ind Crops Prod. 2017; 95:686-694.

4. Priyadarsini KI. Curr Pharm Des. 2013;19:2093-2100.

5. Basir A, Mohanish SB, Ankur PC. Understanding curcumininduced modulation of protein aggregation, Int J Biol Macromol. 2017;100:89-96.

6. Gómez-Estaca J, Balaguer MP, López-Carballo G, Gavara R, Hernández-Muñoz P. Food Hydrocolloids. 2017;70:313-320.

7. Liandong H, Saixi P, Qiaofeng H, Deliang G, Dongqian K, Xiaoyun X, Jianying S. Biomed Pharmacother. 2015;75:26-32.

8. Chainani-Wu N. J Altern Complement Med. 2003;9:161-168.

9. Mark IJ, et al. Cancer Letters. 2015;364:135-141.

10. Sanmukhani J, Satodia V, Trivedi J, et al. Phytother Res. 2014;28:579-585.

11. Suejung GK. Clin Cancer Res. 2011;17:5953-5961.

12. Gopinath D, Ahmed MR, Gomathi K, Chitra K, Sehgal PK, Jayakumar R. Biomaterials. 2004;25:1911-1917.

13. Klippstein R, Bansal SS, Al-Jamal KT. Int J Pharm. 2016;514:169-175.

14. Anand P, Kunnumakkara AB, Newman RA, et al. Mol Pharm. 2007;4:807-818.

15. Siviero A, Gallo E, Maggini V, Gori L, Mugelli A, Firenzuoli F, Vannacci A. Journal of Herbal Medicine. 2015;5:57-70. 
16. Priyadarsini KI. Curr Pharm Des.2013;19:2093-2100.

17. Shen L, Ji HF. Trends Mol Med.2012;18:138-144.

18. Arcamone F, et al. Biotechnol Bioeng. 1969;11:1101-1110.

19. Tacar O, et al. J Pharm Pharmacol. 2012;65:157-170.

20. Minotti G, Menna P, Salvatorelli E, Cairo G, Gianni L. Pharmacol Rev. 2004;56:185-229.

21. Choi JS, Doh KO, Kim BK, Seu YB. Bioorg Med Chem Lett.2017;27:723-728.

22. Vincenzi B, Frezza M, Santini D, Tonini G, Kim H. Expert Opin Emerg Drugs. 2010;15:237-248.

23. Wang JC. Annu Rev Biochem. 1996;65:635-692.

24. Kremer LC, Van Dalen EC, Offringa M, Ottenkamp J, Voute PA, J Clin Oncol. 2001;19:191-196.

25. Wu Q, Yang Z, Nie Y, Shi Y, Fan D. Cancer Lett. 2014;347:159166.

26. Wu L, Leng D, Cun D, Foged C, Yang M. J Controlled Release. 2017;260:78-91

27. Fan Y, et al. Mol Ther Nucleic Acids. 2017;7:181-189.

28. Cui J, Yu B, Zhao Y, et al. Int J Pharm. 2009;371:148-155.

29. Labala S, et al. Int J Pharm. 2017;525:407-417.

30. Wu D, Ma Y, Hou X, Zhang W, Ding Y. Carbohydrate Polymers. 2017; 157:1470-1478.

31. Oh D, Darwish Sh, Shirazi A, Tiwari R, Parang K. Chem MedChem. 2014;9:2449-2453.

32. Mandal D, Shirazi A,Parang K. Angew. Chem. Int. Ed. 2011;50:9633-9637.

33. Shirazi A, Tiwari R, Chhikara B, Mandal D, Parang K.Molecular Pharmaceutics. 2013;10:488-499.
34. Shirazi A, El-Sayed N, Tiwari R, Tavakoli K, Parang K. Current Drug Delivery. 2016;13:409-417.

35. Barlos K, Gatos D, Kallitsis J, Papaphotiu G, Sotiriu P, Wenqing Y, Schäfer W. Tetrahedron Lett.1989;30:3943-3946.

36. Gao C, Liu T, Dang YH, Yu ZY, Wang W, Guo JJ, Zhang XQ, He $\mathrm{GH}$, Zheng $\mathrm{H}$, Yin YH, Kong XQ. Carbohydrate Polymers. 2014;111:964-970.

37. Lee MH, Yang Z, Lim CW, Lee YH, Dongbang S, Kang C, Kim JS. Chem Rev. 2013;113:5071-5109.

38. Cheng R, Feng F, Meng FH, Deng C, Feijen J, Zhong ZY.J Controlled Release. 2011;152:2-12.

39. Ryu K, Kim TI.Arch. Pharmacal Res. 2014;3:31-42.

40. Patterson SD, Katta V. Anal Chem. 1994;66:3727-3732.

41. Wei S, et al. Org Lett. 2007;9:5461-5464.

42. Synthesis of DPCC, Dox-Cyclic Peptide-curcumin Conjugate (10). PyBOP $(0.017 \mathrm{mmol})$ and HOBt $(0.035 \mathrm{mmol})$ was added to a solution of curcumin mono-carboxylic acid (9) $(0.01 \mathrm{mmol})$ in DMF, followed by DIPEA $0.07 \mathrm{mmol}$ ). The reaction mixture was stirred at room temperature for $15 \mathrm{~min}$. A solution of cyclic peptide (7) $(0.011 \mathrm{mmol})$ in DMF was added dropwise under inert conditions. After completion the reaction, the reaction mixture was added dropwise to the cold ether. The orange precipitate was purified using HPLC to afford (10). MALDI-TOF $(\mathrm{m} / \mathrm{z})$ $\left[\mathrm{C}_{147} \mathrm{H}_{184} \mathrm{~N}_{32} \mathrm{O}_{33} \mathrm{~S}_{2}\right]$ : Calcd, 2989.3145; Found 2993.8570 $[\mathrm{M}+4 \mathrm{H}]^{+}$. The purity was confirmed by analytical HPLC. 


\section{Highlights}

- Doxorubicin and curcumin were conjugated with a cell-penetrating peptide.

- Doxorubicin-peptide-curcumin conjugate (DPCC) was synthesized.

- DPCC was found to be more cytotoxic against cancer cells versus normal cells. 